\title{
Realitas Citra Politik Tri Rismaharini
}

\section{Political Image Reality of Tri Rismaharini}

\author{
Ali Sahab \\ Departemen Politik, FISIP, Universitas Airlangga, \\ Jalan Airlangga 4-6 Surabaya 60286. E-mail: ali.sahab@fisip.unair.ac.id \\ Telepon (031) 5034015
}

\begin{abstract}
Tri Rismaharini (Risma) is the Mayor of Surabaya who had successfully led Surabaya during the period of 2010-2015. In 2015 mayoral election, Risma was re-elected as the Mayor of Surabaya. Risma has been known as a mayor who really concerns about environment. During her first tenure, Risma had built many city parks, successfully improved beauty of Surabaya. Such leadership style had attracted the public. In addition, Risma had become a media darling in both printed and electronic media, locally and nationally. This research used survey to capture society's perception toward the leadearship of Risma during 2010-2015. Sample were collected from group leaders and society in general. There are 50 opinion leaders samples consists of academician, businessmen, artist, religious leader, non-governmental organization, politician, and mass media. This research concludes that Risma had successfully constructed her image as a good mayor by conducting populist programs to attract more public attentions than carrying out substantial programs to solve crucial problems as public priorities and needs. It indicates that Risma insisted to frame herself as a caring and lovely leader. In fact, Risma had often become less powerful against the intervention of business persons who had capital strength in Surabaya, East Java, Indonesia.
\end{abstract}

Keywords: Tri Rismaharini, power, image, public opinion, mayor Surabaya, simulacra, reality

\begin{abstract}
Abstrak
Tri Rismaharini (Risma) merupakan Walikota Surabaya yang dinilai sukses memimpin Kota Surabaya 20102015. Pilkada serentak 2015 Risma terpilih kembali sebagai Walikota. Risma dinilai masyarakat Surabaya sebagai walikota yang sangat peduli terhadap lingkungan. Selama Risma menjabat banyak dibangun tamantaman kota yang menambah kecantikan wajah Kota Surabaya. Gaya kepemimpinan di luar pakem inilah yang menyedot perhatian masyarakat. Risma bahkan menjadi media darling baik media cetak maupun elektronik, lokal maupun nasional. Penelitian ini menggunakan metode survey dengan tujuan melihat persepsi masyarakat terhadap kinerja dan kepemimpinan, Tri Rismaharini (Risma) selama lima tahun. Sampel penelitian terdiri dari pemimpin kelompok/komunitas dan masyarakat umum. Sampel opinion leader terdiri dari akademisi, pengusaha, seniman, tokoh agama, LSM, dan aktivis, politisi dan pers. Jumlah sampel yang diambil 50 orang. Sedangkan sampel masyarakat umum sebanyak 384 responden. Simpulan dari penelitian ini adalah selama menjabat Walikota Surabaya periode 2010-2015 kebijakan yang dilakukan Risma hanya melakukan kebijakan yang populis, kebijakan yang hanya menggugah perasaan (emosi) masyarakat saja dan cenderung menyembunyikan realitas yang ada. Selama menjabat Risma cenderung menyembunyikan realitas yang ada, Risma hanya mengerjakan perkerjaan populis dan cenderung menafikkan permasalahan yang lebih besar dan mendasar. Risma juga kurang berdaya atas intervensi kekuatan kapital di Surabaya, Jawa Timur, Indonesia.
\end{abstract}

Kata Kunci: Tri Rismaharini, kekuasaan, pencitraan, opini publik, walikota Surabaya, simulacra, realitas

\section{Pendahuluan}

Tri Rismaharini (Risma) sebagai Walikota Surabaya masa jabatannya berkhir pada tanggal 28 September 2015. Lima tahun sudah Risma memimpin Surabaya dan bersiap mencalonkan diri lagi sebagai walikota untuk periode kedua di Pilkada serentak tangga 9 Desember 2015. Walaupun begitu parpol-parpol belum ada yang akan mencalonkan kadernya untuk melawan incumbent. Sosok Tri Rismaharini (Risma) menjadi momok bagi calon kandidat lain karena popularitas dan elektabilitasnya belum ada yang menyamai apalagi menandingi. Masyarakat Surabaya sangat cinta kinerja dan gaya kepemimpinan Risma yang tidak birokratis, berani dan kerja cepat. Gebrakan Risma sebagai walikota dalam penyediaan public space seperti taman disertai tempat bermain, seperti Taman Bungkul. 
Selama menjabat Risma juga tidak jarang melakukan sidak proyek maupun permasalahan yang dihadapi Surabaya seperti macet, banjir tanpa pengawalan ajudannya, bahkan naik sepeda motor sendiri hanya dengan bermodalkan Handy Talky (HT) untuk koordinasi dengan anak buahnya. Ketika ada kemacetan yang memuncak seperti dipagi hari Risma juga sering turun langsung ke jalan mengatur arus lalu lintas supaya macet segera teratasi. Bahkan pergelangan tangan kiri Risma patah akibat terjatuh saat sidak acara bersih-bersih saluran di Karangrejo, Kelurahan Wonokromo, Kecamatan Wonokromo. Risma juga berani memarahi langsung kontraktor yang nakal maupun pihakpihak yang merusak Taman Bungkul akibat terinjak-injak pengunjung yang berebut es krim gratis dari Walls yang diadakan pada hari Minggu, 11 Mei 2014.

Risma juga merelakan jiwa raganya ketika melaksanakan kebijakan penutupan lokalisasi Dolly yang banyak ditentang oleh berbagai pihak. Risma sudah berpamitan dan meminta suami dan anaknya mengikhlaskan jika dalam penutupan lokalisasi Dolly dirinya pulang ke rumah tinggal nama. Perjuangan dan kecintaannya terhadap Kota Surabaya ini membuat banyak masyarakat Surabaya yang jatuh cinta dengan Risma dan diharapkan maju lagi dalam pemilihan. Mayoritas pemilih Risma pada Pilkada 2010 masih menginginkan Risma menjadi Walikota Surabaya untuk periode 2015-2020.

Pasangan Tri Rismaharini-Bambang DH pada Pilkada 2010 memperoleh suara signifikan, yaitu sebesar 40,9 persen, mengalahkan pasangan Arif-Afandi-Adies Kadir yang hanya memperoleh 36 persen. Namun di tengah perjalanan Bambang DH mengundurkan diri karena maju sebagai calon gubernur periode 2014-2019 dan digantikan oleh Wisnu Sakti Buana pada tanggal 24 januari 2014.

Kebijakan pertama Risma setelah terpilih sebagai walikota yaitu mencegah Kota Pahlawan menjadi 'hutan reklame' seperti kota-kota besar lainnya. Selain merusak pemandangan kota, berdirinya 'hutan reklame' juga bisa mengancam keselamatan pengguna jalan. Papan reklame besar bisa saja menimpa pengguna jalan seperti kasus di beberapa kota besar lainnya. Sementara pemotongan pajak untuk papan reklame kecil semata-mata untuk memacu pengusaha menengah ke bawah agar lebih mudah beriklan. Namun hal ini justru memicu konflik Risma dengan DPRD Kota Surabaya. Hubungan Risma dan DPRD Kota Surabaya menjadi kurang harmonis. Konflik di awal-awal pemerintahan Risma membuat Risma mencari dukungan dari luar legislatif yaitu media massa dan masyarakat Surabaya.

Setiap kegiatan Risma selalu diliput oleh media baik media cetak maupun elektronik. Bahkan kegiatan Risma yang sering terjun sendiri mengatur lalu lintas yang macet, selalu mematau daerahdaerah banjir di Surabaya, ikut membersihkan saluran air dan taman, dan tidak jarang memarahi orang yang merusak taman membuat media lokal dan nasional tertarik untuk meliput. Lama kelamaan Risma menjadi media darling atau tokoh yang disukai media massa karena setiap tindakannya memberikan sentuhan, apresiasi masyarakat dan layak tayang. Tindakan Risma yang diliput oleh media massa secara terus menerus bisa membentuk nilai (citra) baik positif maupun negatif dan opini publik. Opini publik yang disampaikan melalui media massa secara terus menerus bisa membentuk sikap dan perilaku seseorang atau masyarakat. Pencitraan politik merupakan hal yang biasa dilakukan dalam dunia politik, namun harus sesuai dengan realitas yang ada. Apakah pencitraan yang dilakukan oleh Risma memang sesuai dengan realitas atau menyembunyikan realitas yang ada?

\section{Metode Penelitian}

Artikel ini merupakan hasil penelitian dengan menggunakan metode survey dengan tujuan melihat persepsi masyarakat terhadap kinerja dan kepemimpinan, Tri Rismaharini (Risma) selama lima tahun. Survey ini juga melihat isu-isu dan problematika yang ada di masyarakat. Survey ini dilakukan pada masyarakat pembentuk opini (opinion leader) dan masyarakat umum. Sampel untuk opinion leader dengan menggunakan purposive, sedangkan sampel pada masyarakat umum menggunakan stratified random sampling. Sampel opinion leader terdiri dari Akademisi, Pengusaha, Seniman, Tokoh Agama, LSM, dan Aktivis, Politisi dan Pers. Jumlah sampel yang diambil 50 orang, dan sampel dari masyarakat umum sebanyak 384 responden. 
Pengumpulan data selain wawancara langsung setiap responden dengan menggunakan kuesioner, peneliti juga melakukan observasi langsung kondisi di lapangan berkaitan dengan isu-isu dan program yang menjadi keinginan masyarakat. Pertanyaan dalam kuesioner tersebut berisi karakteristik responden yang meliputi kecamatan tempat tinggal, jenis kelamin, agama, pendidikan, pekerjaan, dan penghasilan. Responden juga ditanya tentang evaluasi kinerja Risma, program apa yang dinilai sukses dan program apa yang dinilai kurang atau perlu diperhatikan. Responden juga ditanya tentang citra Risma, baik citra positif maupun citra negatif. Dari data yang diperoleh seperti program yang dinilai kurang oleh responden di kroscek dengan penyerapan anggaran masing-masing dinas yang tertuang dalam Laporan Kinerja Pemerintah Kota Surabaya Tahun 2014.

Lokasi penelitian ini di seluruh Kecamatan yang ada di Surabaya, yaitu sebanyak 31 kecamatan. Responden di bagi secara proporsional di masing-masing kecamatan sesuai dengan luas wilayah dan jumlah pemilih. Data yang diperoleh dari lapangan akan di entri dengan menggunakan program SPSS 17, setelah itu dilakukan cleaning data untuk mengecek kesalahan data. Analisis dilakukan dengan melakukan generalisasi data atas fenomena yang terjadi di masyarakat.

Kesulitan dalam penelitian ini terjadi ketika mencari data untuk menjawab hipotesis tentang pencitraan yang dilakukan oleh Risma. Peneliti mencari data dari penyerapan anggaran masingmasing Dinas yang tertuang di Laporan Kinerja Pemerintah Kota Surabaya Tahun 2014. Untuk mendapatkan data tersebut peneliti meminta jaringan LSM di Surabaya, namun tidak mempunyai laporan tersebut dan disarankan langsung ke DPRD Kota Surabaya. Walaupun ini data publik, namun kadang ketika masyarakat meminta data agak kesulitan, sehingga peneliti menggunakan kenalan anggota DPRD Kota Surabaya yang kebetulan bertugas di komisi yang membidangi pemerintahan. Laporan Kinerja Pemerintah Kota Surabaya Tahun 2014 menunjukkan detail penyerapan anggaran tiap dinas dan ternyata banyak anggaran, padahal sangat penting untuk pemberdayaan masyarakat banyak.

\section{Hasil dan Pembahasan}

Pencitraan politik pada awal abad XX sudah dilaksanakan di Amerika Serikat. Dalam pemilihan yang mendasarkan pada pilihan mayoritas mengharuskan seorang kandidat untuk membentuk opini publik yang diharapkan akan mempengaruhi sikap dan perilaku politik. Menurut Nimmo (1976) citra adalah segala hal yang berkaitan dengan situasi keseharian seseorang, menyangkut pengetahuan, perasaan dan kecenderungannya terhadap sesuatu, sehingga citra dapat berubah seiring dengan perjalanan waktu. Di Indonesia sendiri perkembangan pencitraan politik (political image) berkembang sejak pemilihan langsung tahun 2004. Segala tindakan yang dilakukan Risma atas dasar kekuasaannya sadar atau tidak sadar merupakan pencitraan politik. Citra politik yang terbentuk di benak publik, tidak selamanya sesuai dengan realitas yang sebenarnya, karena mungkin hanya sama dengan realitas media atau realitas buatan media yang disebut juga realitas tangan kedua (second hand reality). Pencitraan politik bisa mempengaruhi opini publik dengan terbentukknya opini publik di masyarakat bisa mempengaruhi sikap dan perilaku politik seseorang. Tindakan masyarakat atas dasar pencitraan itu bisa rasional sekaligus emosional seperti dua keping mata uang. Adanya pengaruh pencitraan politik terhadap opini publik dan pilihan pemilih juga bisa dilihat dari penelitian yang berjudul Creating a Political Image: Shaping Appearance and Manipulating The Vote (Rosenberg et al. 1991). Pilihan masyarakat bisa dibentuk melalui pembuatan citra positif kandidat melalui perbaikan penampilan di media massa.

Seorang kandidat harus berpenampilan menarik atau dibentuk pendukung pemilih yang simpatik pada kandidat. Membentuk penampilan kandidat berkembang di negara demokrasi yang banyak menggunakan media televisi sebagai media kampanye seperti di Amerika Serikat, Inggris, Jepang dan Yunani. Pencitraan politik di Indonesia juga mulai berkembang pasca reformasi, khususnya pada Pemilu Presiden 2004. Di Amerika Ronal Reagan dikenal sebagai "great communicator" begitu pula di Surabaya, Risma dicitrakan sebagai walikota yang mampu mempercantik Surabaya dengan 
membuat taman-taman kota dan Risma juga dicitrakan sebagai walikota yang sering terjun langsung ke bawah untuk mengontrol kondisi di lapangan.

Dalam pencitraan terdapat dua elemen dasar yaitu 1) positioning, bagaimana menempatkan produk dalam pikiran konsumen (Trout J \& Ries A 1982). Risma ketika berkonflik dengan DPRD Kota Surabaya dalam setiap wawancara di media memposisikan dirinya sebagai pihak teraniaya oleh anggota dewan karena kebijakannya yang dirasa benar. Risma berusaha menertibkan reklame dengan tujuan mengurangi jumlah reklame terutama yang berukuran kecil. Risma dimata khalayak ramai juga memposisikan dirinya sebagai pemimpin yang pro rakyat (kecil) dekat dengan rakyatnya dengan seringnya ikut membersihkan taman, mengatur lalu lintas ketika macet, dan Risma juga peduli dengan lingkungan (taman). Risma sangat marah jika ada pihak-pihak yang merusak tamannya dan tidak segan Risma berkata "kasar" namun itu tidak menjadi masalah bagi pendukung/pemilih Risma karena sebagai bentuk keberpihakan Risma atas pengrusakan taman dari pihak-pihak tertentu. 2) memory, manusia pada dasarnya menyeleksi informasi yang disimpan dalam memorinya, hanya hal-hal yang dinilai penting yang disimpan. Manusia juga cenderung menangkap pesan yang sederhana atau tidak terlalu rumit. Dalam kegiatan setiap harinya Risma selalu langsung memberi contoh seperti ketika ada kemacetan, langsung terjun ikut mengatur lalu lintas, sidak daerah-daerah banjir, ikut membersihkan taman dan saluran air. Tindakan-tindakan itu dilakukan Risma secara terus menerus dan menancap dalam pikiran masyarakat bahwa Risma merupakan sosok walikota yang peduli terhadap permasalahan kota.

Apa yang dilakukan Risma ini memang bisa memberikan citra positif karena pemberitaan media massa. Namun apa yang dilakukan Risma ini tidak seharusnya dilakukan secara terus menerus oleh Risma sendiri karena bisa didelegasikan kepada Wakil Walikota atau Kepala Dinas. Jika ini dilakukan secara terus menerus oleh Risma maka akan terjebak pada pencitraan politik semata yang tidak ada kaitannya dengan problem yang dihadapi Surabaya. Risma sebagai walikota bisa konsentrasi berkaitan dengan kebijakan-kebijakan yang lebih besar. Risma memang sangat berkepentingan dengan pembentukan citra positif guna membentuk opini publik dan bisa mempengaruhi sikap dan perilaku politik warga Surabaya. Harapannya citra positif tersebut dikonversikan dalam bentuk dukungan dalam Pilkada 2015.

Popularitas Risma sebagai Walikota Surabaya tumbuh sejak massa pencalonan Risma sebagai Walikota Surabaya periode pertama. Kedekatan dengan media massa menjadi keuntungan sendiri bagi Risma. Sehingga apa pun yang dilakukan Risma selalu menjadi berita dan menjadi perbincangan di masyarakat Surabaya. Risma sendiri seperti yang diungkapkan oleh Kendall \& Paine (1995:69) seleksi kandidat diawali oleh peran media masa yang membentuk image. Untuk menggambarkan proses tersebut Kendall \& Paine (1995) membuat A Basic Model of Candidate Image Formation (CIF) seperti pada Gambar 1.

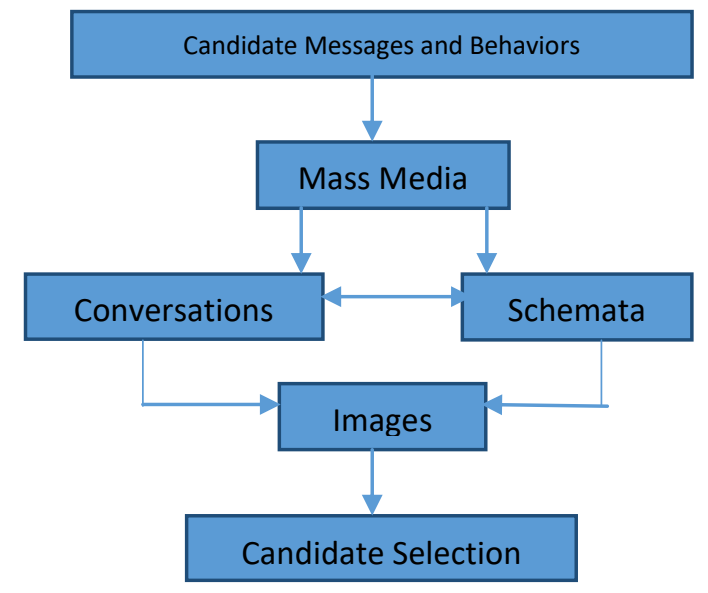

Gambar 1.

A Basic Model of Candidate Image Formation (CIF) 
Pemilih akan memproses dan mengolah apa yang menjadi pesan dan apa yang kandidat lakukan (Davis \& Owen 1998, Neuman 1986). Setelah masyarakat melihat kandidat di media massa mereka menjadikan bahan perbincangan baik orang per orang maupun dalam kelompok masyarakat (Davis \& Owen 1998, Hacker 1996). Sehingga pesan dan perilaku Risma dengan cepat tersebar dengan sendirinya kepada masyarakat Surabaya pada khususnya dan Risma juga menjadi populer di dalam dan luar negeri. Schemata merupakan justifikasi atau penguatan berita tentang pesan dan perilaku kandidat dengan data dari media massa. Keberhasilan Risma dalam mengelola Surabaya ditonjolkan dengan pemberitaan terus menerus dengan didukung oleh data yang disajikan oleh media massa. Walaupun data sebenarnya yang sesuai realitas kadang kala cenderung ditutupi. Misalnya berkaitan dengan pembangunan Monorail dan Trem yang selalu diberitakan akan dibangun tahun 2015 dan akan selesai tahun 2017. Risma selalu mensosialisasikan dengan adanya kendaraan massal yang cepat dan murah bisa mengurangi kemacetan di Surabaya. Masyarakat tidak banyak yang tahu bahwa proyek tersebut sudah menjadi proyek nasional artinya yang memutuskan untuk pelaksanaannya adalah pemerintah pusat, sehingga pembangunan Monorail dan Trem tidak bisa Risma sebagai Walikota Surabaya menentukan waktunya sendiri. Pemerintah Kota Surabaya (Pemkot) tahun 2014 ternyata menyusun Perda No.12 Tahun 2014 tentang Rencana Tata Ruang Wilayah (RTRW) Kota Surabaya Tahun 2014-2034. Dalam RTRW memang sudah diatur pengembangan angkutan massal cepat yaitu pasal 26 ayat 2 (b) pengembangan angkutan massal kota berbasis rel sebagaimana dimaksud pada ayat (2) huruf a, dengan alternatif pengembangan angkutan massa cepat (Mass Rapid Transit), yang melalui rute antara lain pada koridor timur-barat kota dan koridor utara-selatan kota. Walaupun sudah diatur namun ketika kita lihat pada Lampiran III Tanggal 22 Agustus 2014 tentang Tahapan Pelaksanaan Pembangunan untuk komponen transportasi perkeretaapian dalam kota dengan program pengembangan angkutan massal kota berbasis rel dengan alternatif pengembangan angkutan massal cepat (mass rapid transit) baru akan dilakukan tahun 2017, sehingga apa yang disampaikan tidak sesuai dengan aturan yang sudah dibuat sendiri oleh Risma. Dalam Gambar 1. di atas images dipengaruhi oleh apa yang menjadi perbincangan di masyarakat dan dipengaruhi oleh pesan media massa (Hacker 1996). Perbincangan image tentang Risma yang dibentuk oleh media massa pada akhirnya bisa mempengaruhi pemilih dalam menyeleksi kandidat (Nimmo \& Savage 1976, Kendall \& Yum 1984).

Seperti yang dikemukakan oleh Baudrilllard (2006), bahwa citra memiliki empat bentuk: (1) it is the reflection of a basic reality (2) it masks and perverts a basic reality (3) it masks the absence of a basic reality (4) it bear no relation to any reality whatever: it is its own pure simulacrum. Pencitraan politik merupakan tindakan yang tidak bisa dinafikkan di era demokrasi liberal. Untuk mengetahui kebijakan Risma yang telah dilakukan selama menjabat sebagai Walikota Surabaya periode pertama apakah sesuai dengan realitas atau justru tidak ada kaitannya dengan realitas bisa dilihat dari data survey dengan membandingkan data masyarakat umum dan data dari masyarakat yang menguasai informasi, akses terhadap sistem politik serta mampu membentuk opini dalam masyarakat (opinion leader).

\section{Evaluasi Masyarakat terhadap Pemerintahan Tri Rismaharini}

Selama pemerintahan Tri Rismaharini (Risma) banyak penghargaan yang diraih, baik itu penghargaan di tingkat nasional maupun tingkat internasional. Masyarakat sangat berkesan terhadap gebrakan Risma tentang penghijauan di beberapa tempat di Surabaya termasuk dengan membuat dan memperbaiki taman yang ada. Penyediaan ruang publik yang nyaman dan disertai fasilitas bermain dan jaringan internet seperti Taman Bungkul mengantarkan Surabaya mendapatkan penghargaan sebagai kota yang terbaik partisipasinya Se-Asia Pasifik Tahun 2012 versi Citynet. Surabaya dinilai berhasil dalam menjalin kerjasama antara Pemerintah Kota dengan rakyat dalam berpartisipasi mengelola lingkungan.

Tri Rismaharini dalam menanggulangi banjir di Kota Surabaya dengan merevitalisasi saluran air yaitu dengan program box culvert. Dengan box culvert saluran air bisa lancar karena volumenya besar dengan konstruksi yang kuat, sehingga jika hujan air langsung mengalir. Dari beberapa hal di atas bisa dilihat tingkat kepuasan terhadap kinerja Tri Rismharini selama 5 tahun. Evaluasi dilakukan di tingkat masyarakat umum (massa) dan di kalangan elit atau opinion leaders. Persepsi di kedua kelas 
sosial ini bertujuan untuk membandingkan persepsi masing-masing kelas sosial apakah terjadi kesamaan atau perbedaan. Survey di kalangan opinion leader diasumsikan tahu dengan baik program kerja Tri Rismaharini serta aplikasi dari program-program yang ada. Opinion leader ini dengan kemudahan akses informasi dan jaringan diasumsikan mengetahui peristiwa politik baik panggung depan maupun panggung belakang.

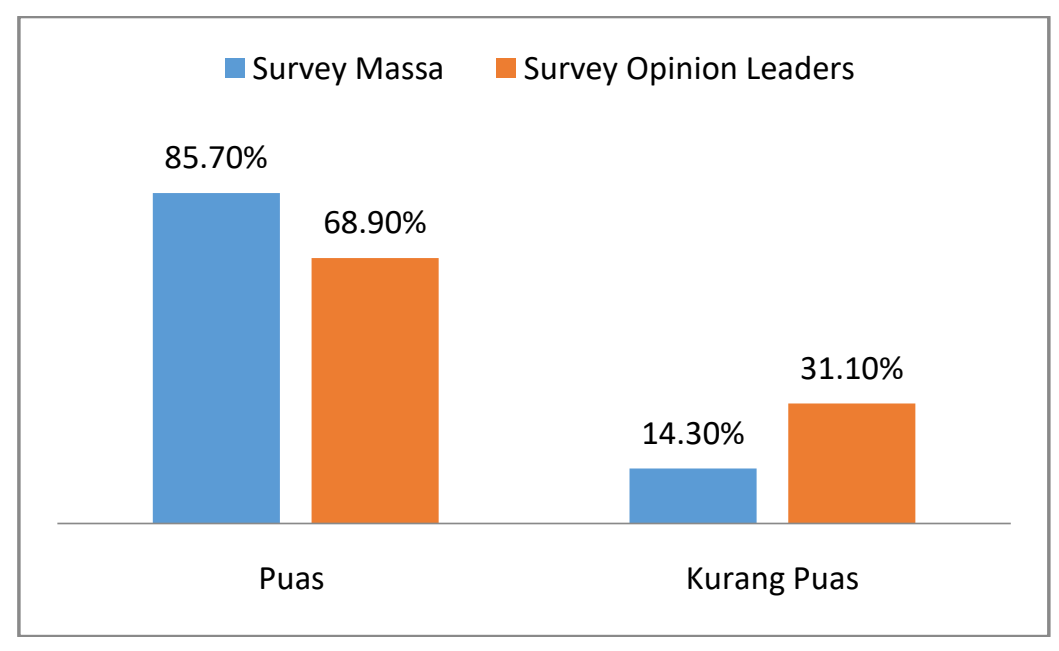

\section{Diagram 1.}

Evaluasi Kinerja Risma

Sesuai Diagram 1, masyarakat ditanya tentang kepuasan terhadap kinerja selama menjabat, mayoritas masyarakat menjawab puas, yaitu sebesar $85,7 \%$ sedangkan yang kurang hanya $14,3 \%$. Sedangkan survey di tingkat opinion leader lebih banyak yang sudah puas, namun tidak setinggi kepuasan di survey massa. Responden yang menilai puas survey opinion leader hanya $68,90 \%$, lebih rendah $16,8 \%$, sedangkan yang kurang puas mencapai $31,10 \%$ lebih tinggi $16,8 \%$ dari responden yang kurang puas pada survey massa. Berdasarkan Diagram 1 di bawah bisa dilihat bahwa kepuasan opinion leader lebih rendah atau yang kurang puas lebih banyak daripada survey massa. Ini menunjukkan bahwa ada beberapa bidang yang dinilai perlu mendapatkan perhatian lebih karena dinilai masih kurang.

Sesuai dengan Diagram 2 bahwa selama Risma menjabat program yang dinilai berhasil diantaranya seperti penyediaan taman, pembangunan infrastruktur dan penanganan terhadap banjir. Dalam penyediaan taman baru maupun perbaikan taman yang ada dinilai program yang paling berhasil, yaitu sebanyak $60,8 \%$ survey massa dan $60,2 \%$ survey opinion leader. Tingginya apresiasi masyarakat terhadap taman di Surabaya ini memang terlihat nyata karena Surabaya semakin hijau dan dinilai sebagai kota ramah lingkungan. Mulai Tahun 2011, 2012, 2013, dan 2014 Kota Surabaya selalu mendapatkan Piala Adipura untuk kategori Kota Metropolitan. Selain itu. selama dipimpin oleh Tri Rismaharini, Surabaya juga menjadi kota yang terbaik partisipasinya Se-Asia Pasifik Tahun 2012 versi Citynet. Surabaya dinilai berhasil dalam menjalin kerjasama antara Pemerintah Kota dengan rakyat dalam berpartisipasi mengelola lingkungan. Berkat program Risma untuk menambah ruang terbuka hijau, sekarang di Surabaya ruang terbuka hijau (taman) mencapai 50 lebih tempat, tersebar di berbagai tempat. 


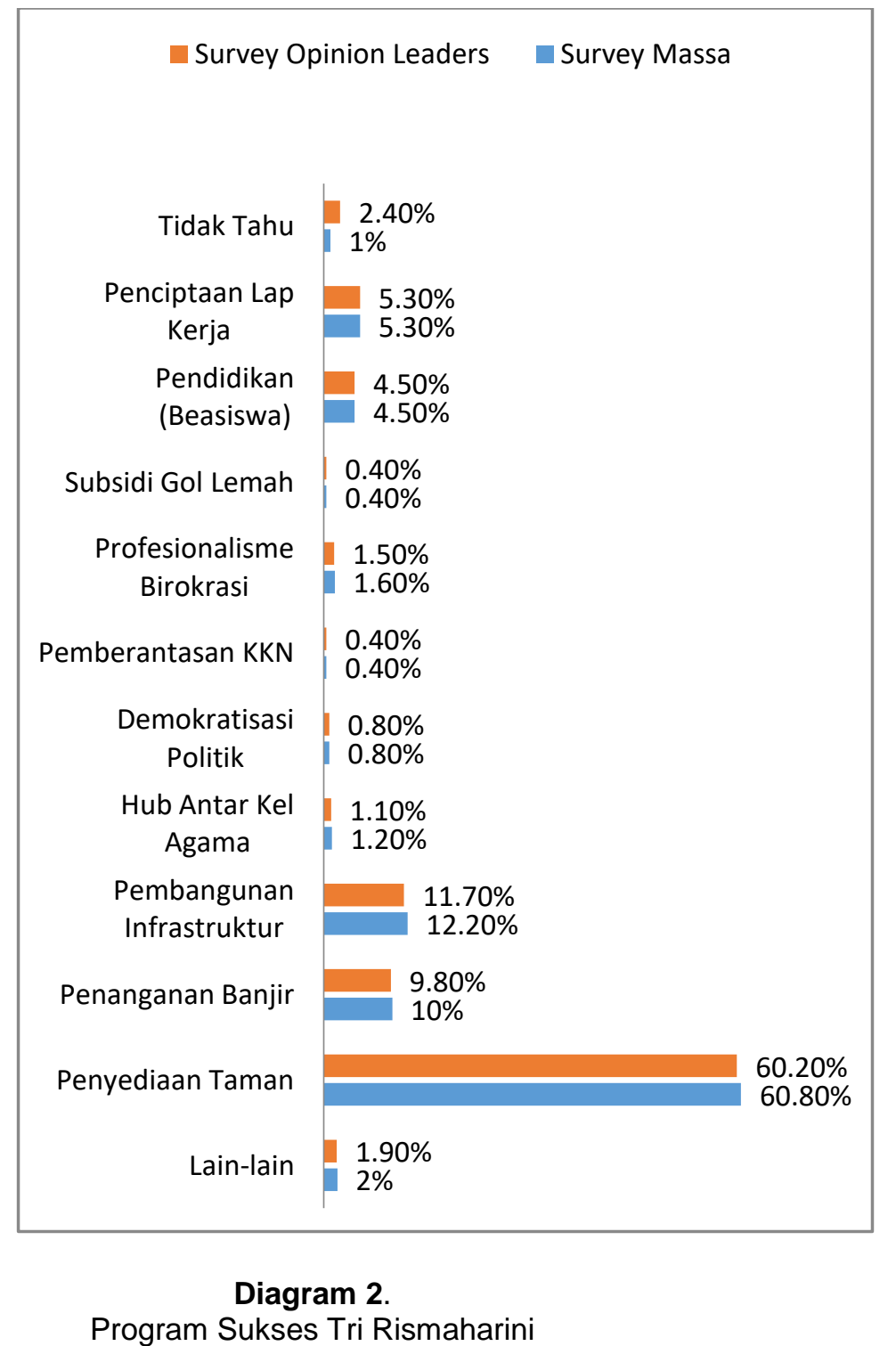

Program Risma yang dinilai sukses kedua yaitu pembangunan infrastruktur seperti pembangunan dan perbaikan jalan, jembatan, maupun saluran air. Antara survey massa dan opinion leaders tidak berbeda jauh, survey massa pembangunan infrastruktur dinilai sukses oleh 12,2\% responden, sedangkan survey massa menilai sebanyak $11,70 \%$ responden juga merasakan kepuasan program Risma dalam pembangunan infrastruktur. Program sukses ketiga Risma yang dinilai sukses yaitu penanganan banjir. Penanganan banjir di Surabaya sudah dirasakan masyarakat, hal ini bisa dilihat dari genangan airnya yang tidak begitu lama. Penanganan banjir dinilai responden sukses sebesar $10 \%$ untuk survey massa, dan 9,8\% untuk survey opinion leaders. Hal ini menggambarkan antara keduanya memiliki persepsi yang sama berkaitan dengan program penanggulangan banjir di Kota Surabaya.

Pemkot Surabaya bekerjasama dengan pemerintah pusat membangun infrastruktur di Surabaya, seperti jalan dan saluran air. Pembangunan jalan seperti frontage road yang berada di sebelah barat dan timur Jl. A. Yani serta pembangunan Middle East Ring Road (MERR) II C tujuan utamanya yaitu untuk mengurangi kemacetan di Jl. A.Yani terutama di jam-jam padat seperti pagi dan sore hari. Dengan adanya penambahan jalan walaupun cukup mengurangi kemacetan namun hanya sementara, karena perbandingan volume penambahan jalan baru dengan jumlah kendaraan bermotor tidak sebanding. Sehingga walaupun ditambah berapapun jalan tapi jumlah kendaraan bermotor seperti sepeda motor dan mobil tidak dibatasi, kemacetan tetap saja akan terjadi. Kantong-kantong kemacetan selain Jl.A.Yani yaitu di Surabaya Barat seperti Lakartasantri, Mayjen Sungkono dan Tambak Oso 
Wilangun. Dari data lalu lintas Dinas Perhubungan Kota Surabaya akhir tahun 2013 lalu, jumlah kendaraan yang melewati wilayah Surabaya Barat terus mengalami peningkatan yang cukup signifikan.

Program ketiga yang dinilai cukup sukses selama Tri Rismaharini menjabat sebagai Walikota Surabaya yaitu penanggulangan banjir. Saluran air di Kota Surabaya direvitalisasi dengan menggunakan box culvert sehingga ketika hujan air bisa mengalir lancar, sehingga genangan air berlangsung tidak lama. Seperti hujan selama 4 jam yang terjadi Senin, 19 Januari 2015 membuat banjir merata di seluruh wilayah Surabaya. Wilayah yang sering dilanda banjir seperti disekitar wilayah Pemerintah Kota Surabaya, Jl. Jimerto, Jl. Gubernur Suryo, Jl. Tegalsari, Jl. Gubeng, Jl. Petemon, Jl. Tanjungsari dan Jl. Dharmawangsa. Penanganan banjir oleh Pemkot Surabaya memang belum maksimal, namun yang bisa dikurangi yaitu waktu genangan air. Dengan adanya revitalisasi saluran air dengan menggunakan box culvert seperti di bawah ini diharapkan banjir bisa berkurang. Dengan menggunakan box culvert ini saluran air bisa dialih fungsikan sebagai jalan untuk mengantasi kemacetan. Keberhasilan Risma dalam dalam usahanya memperbanyak ruang terbuka hijau (taman kota) menjadi pemberitaan yang masif sehingga ketika pemberitaan keberhasilan Risma dilakukan secara terus menerus oleh media massa maka bisa mempengaruhi opini publik (public opinion). Namun keberhasilan Risma apakah sesuai dengan realitas atau akibat pencitraan oleh media massa yang berdampak pada pembentukan opin publik perlu dilihat dari apa yang menjadi keluhan atau persepsi masyarakat tentang kinerja Risma yang masih kurang. Menurut Walter Lippmann (1946:11), "The symbols of public opinion, in times of moderate security, are subject to check and comparison and argument". Jadi masyarakat dalam menerima informasi atau berita perlu mengecek kebenarannya dan membandingkan dengan pemberitaan yang lain atau realitas yang ada. Masyarakat juga perlu dan diperbolehkan mengemukakan pendapat walaupun berbeda dengan pemberitaan yang ada atau opini publik yang sudah terbentuk sebagai pembanding dan sebagai upaya untuk menemukan realitas.

Program yang masih dinilai kurang oleh responden selama Risma memimpin yang paling tinggi sesuai Diagram 3, yaitu penciptaan lapangan kerja yang dinilai masih kurang. Sebanyak 20,50 persen responden survey opinion leader menilai selama menjabat Pemerintah Kota Surabaya masih kurang dalam penciptaan lapangan kerja. Sedangkan 20 persen dari responden survey massa. Program kedua yang dinilai kurang yaitu pengentasan kemiskinan, 19,70 persen responden survey opinion leader menilai Pemkot Surabaya masih kurang, dan 20,40 persen responden survey massa juga menilai kurang. Penanganan banjir juga dinilai oleh responden masih kurang, walaupun sudah dilakukan rehabilitasi saluran air oleh Pemkot dengan menggunakan box colvert, namun banjir masih tetap saja terjadi dan masyarakat masih berharap penanganan banjir lebih besar lagi. Sebagai program ketiga yang dinilai kurang 14 persen oleh responden opinion leaders sedangkan sebanyak 14,7 persen responden survey massa menilai hal yang sama.

Seberapa besar keberpihakan Risma selama menjabat terhadap penciptaan lapangan kerja dan pengurangan kemiskinan bisa dilihat dari penyerapan anggaran di dua dinas yaitu Dinas Tenaga Kerja dan Dinas Koperasi dan Usaha Kecil Menengah. Dua dinas ini yang menangani langsung berkaitan dengan ketenagakerjaan dan penumbuhan usaha mandiri masyarakat melalui bantuan koperasi untuk UMKM. Namun ternyata di dua dinas ini penyerapan anggarannya tidak maksimal. Di Dinas Tenaga Kerja penyerapan anggaran Tahun 2014 berdasarkan Laporan Kinerja Keuangan Pemerintah Kota Surabaya hanya 73,74 persen dari total anggaran Rp22.468.765.331, yang terserap hanya Rp16.567.501.464. Jadi sisa anggaran sebesar Rp5.901.263.867. Hal ini menunjukkan bahwa rendahnya penyerapan anggaran di Dinas Tenaga Kerja berimplikasi terhadap masyarakat langsung. Dan ini terpotret pada program yang dinilai kurang oleh masyarakat. Seharusnya dengan dana sebesar itu bisa dimaksimalkan lagi untuk pengurangan pengangguran, melalui pelatihan-pelatihan yang menunjang ekonomi kreatif. Masyarakat selain dilatih juga dibantu berkaitan dengan pelatihan pengemasan, jaringan pemasaran produk dan yang sangat penting yaitu bantuan modal usaha dengan bunga rendah dan tanpa agunan.

Penyerapan anggaran Program Peningkatan Kesempatan Kerja yang paling rendah yaitu identifikasi perkembangan kondisi ketenagakerjaan yaitu hanya 12,12 persen dari total anggaran Rp. 330.138.200 
hanya terserap Rp40.000.000. Program ini sebetulnya merupakan program dasar untuk memetakan jenis pekerjaan yang memang lagi dibutuhkan oleh industri atau yang bisa bertahan sebagai usaha kreatif mandiri. Ketika Dinas Tenaga Kerja tidak bisa mengidentifikasi maka bagaikan orang buta yang tidak tahu kemana arah tujuan. Ketika ekonomi yang menghimpit yang menyebabkan pengangguran meningkat maka sebagian masyarakat memilih untuk berjualan makanan dan karena tidak mempunyai tempat mereka kebanyakan jualan di tepi jalan dengan memakai trotoar. Dampak negatifnya mengganggu pengguna jalan dan estetika kota, maka dari itu Risma sebagai walikota sering menertibkan Pedagang Kaki Lima (PKL) karena berjualan pada tempat yang tidak semestinya. Walaupun sudah melakukan penataan PKL namun tahun 2014 penyerapan anggaran untuk penataan tempat berusaha bagi PKL dan asongan hanya 61,27 persen dari Rp15.302.283.640. pada 2011 terdapat 13.015 pedagang yang tersebar di 489 titik. Penetaan PKL dilakukan dengan berlandaskan Perda 17 Tahun 2003 tentang Penatan dan Pemberdayaan Pedagang Kaki Lima (PKL).

Di Tahun 2011 ada 19 sentra PKL yang sudah berdiri dengan APBD sebesar Rp9.213.791.159. Tahun 2014 Pemkot menargetkan akan terbangun 10 sentra PKL yang diperkirakan dapat menampung sekitar 1.000 hingga 2.000 PKL. Namun hendaknya dalam pendirian sentra PKL harus dikaji keberlanjutan program tersebut, khususnya ada tidaknya pembeli. Sentra PKL seperti di Sukomanunggal, Urip Sumoharjo akhirnya mati karena tidak ada yang beli. Namun disisi lain Pemkot Surbaya melaku Dinas UMKM nya tetap berusaha untuk menambah jumlah sentra PKL, tahun 2015 ditargetkan delapan sentra PKL dengan dana Rp8.000.000.000. Gencarnya pembangunan sentra PKL, Risma dinilai terlalu mengejar kuantitas, tidak menghiraukan sentra-sentra PKL yang ternyata tidak bisa bertahan. Berdasarkan data Dinas Koperasi dan UMKM dari 50 sentra PKL ada 7 sentra PKL yang gulung tikar. Tujuh sentra PKL tersebut seperti di Sumberejo, Kandangan, Lidah Wetan, Pakal, Sememi semuanya di wilayah Surabaya barat dan dua lagi di Jl. Urip Sumoharjo dan Ampel. Ratarata menyediakan 40 stan namun hanya terisi 10 sampai 15 stan saja.

Program penanganan banjir penyerapan anggarannya hanya 84,41 persen, dari total anggaran Rp450.077.720.147. Alokasi dana paling besar diperuntukkan rehabilitasi saluran drainase/sungai sebesar Rp227.357.487.961 hanya terserap 82,37 persen. Hal ini seharusnya bisa dimaksimalkan lagi sehingga bisa mengurangi daerah langganan banjir. Wilayah Surabaya yang sering terkena banjir yaitu Kecamatan Pakal dan Benowo karena luapan Kali Lamong. Titik-titik lain yang tergenang air antara lain Gubeng, Tenggilis, Mulyorejo, Sukolilo, Rungkut, Mayjen Sungkono,Indragiri, Adityawarman Sedangkan wilayah Surabaya Utara Asem Mulyo, Simo Rejo, Simo Mulyo. Pemkot Surabaya dalam pengendalian banjir menambah 17 rumah pompa baru, seperti di Pesapen, Gadukan, Kalibokor, dan Kalidami. Upaya lainnya yaitu pengerukan sungai sejak Januari-Oktober 2015 dengan hasil pengerukan sebanyak $205.000 \mathrm{~m}^{3}$ yang diangkut 41.791 truk.

Pada Diagram 3 dapat dilihat bahwa apa yang dipersepsikan masyarakat atas keberhasilan Risma, ternyata tidak sesuai dengan apa yang memang menjadi kebutuhan masyarakat Surabaya. Kebutuhan mendasar masih menjadi harapan masyarakat. Sebagai masyarakat perkotaan seharusnya permasalahannya bukan lagi pada persoalan mendasar, seharusnya bergeser pada permasalahan yang terkait kebutuhan publik dan penataan kota seperti penanganan banjir, transportasi serta penurunan pajak, namun selama Risma menjabat Walikota Surabaya 2010-2015 hal tersebut masih banyak dikeluhkan. 


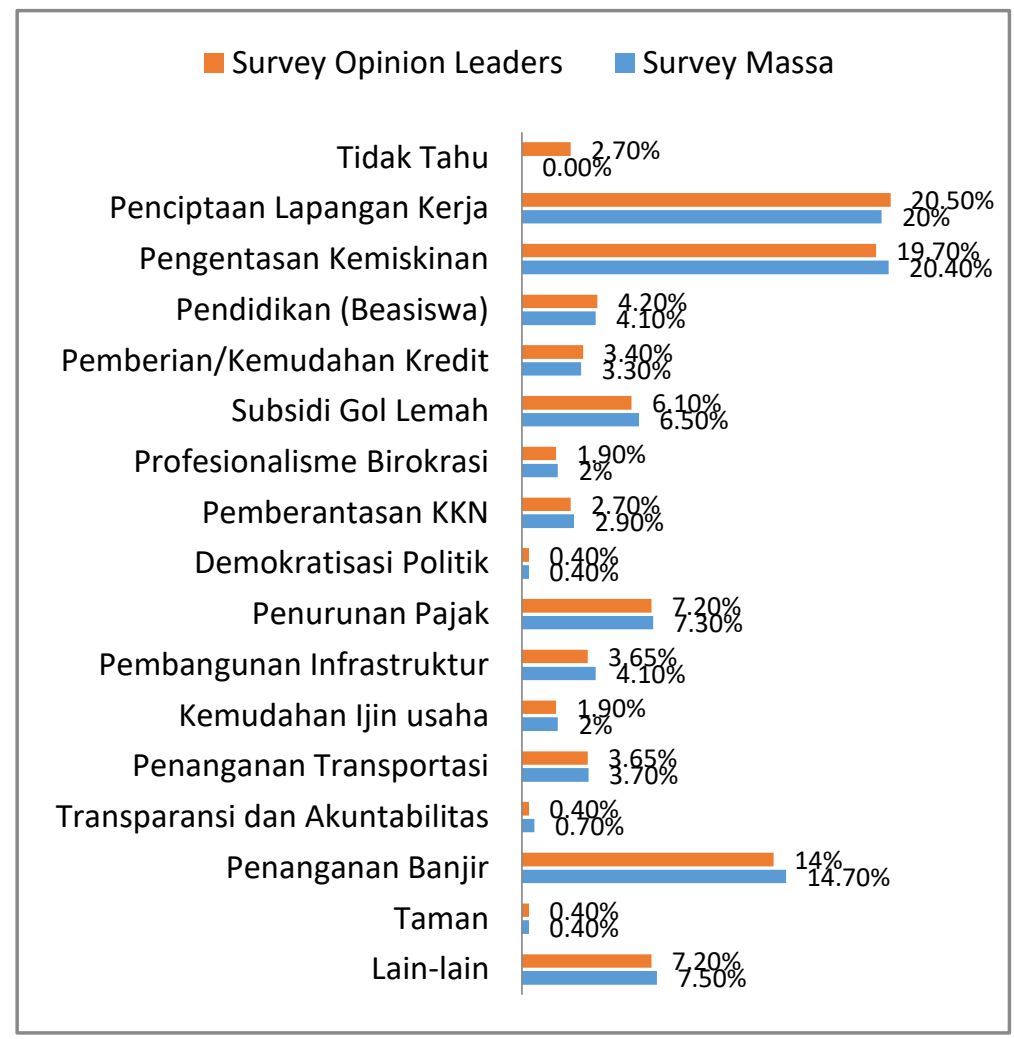

Diagram 3.

Program Kekurangan Tri Rismaharini

\section{Persepsi masyarakat terhadap pribadi Risma}

Sosok Tri Rismaharini di mata masyarakat Surabaya merupakan walikota yang berbeda dari walikota Surabaya sebelum-sebelumnya. Risma berani mendobrak budaya pejabat yang formal, Risma tidak jarang mengontrol seperti banjir, macet tanpa pengawalan bahkan Risma turun sendiri ikut membantu menangani banjir dan macet. Risma tidak segan-segan marah jika ada pihak yang tidak bertanggungjawab merusak tamannya. Setelah Risma menjabat juga banyak menambah taman-taman baru untuk menghijaukan kota. Surabaya yang sebelumnya panas sekarang hijau dengan banyak taman di Surabaya. Apa yang dilakukan oleh Risma sebagai walikota, sehingga Risma sering diberitakan oleh media massa atau biasa disebut media darling. Di awal pencalonannya Risma memang sudah banyak didukung oleh media massa seperti media cetak terbesar di Jawa Timur. Peran media massa juga berpengaruh pada persepsi dan citra terhadap Risma selama menjabat Walikota Surabaya. Di bawah ini merupakan citra positif Risma sebagai walikota. Dari survey massa citra positif yang paling tinggi, yaitu Risma peduli dengan lingkungan 33,9\%. Risma membangun tamantaman kota dan merevitalisasi ruang terbuka yang tidak berfungsi dijadikan taman. Sedangkan survey opinion leaders citra positif Risma yaitu Risma walikota yang sering turun ke bawah yaitu sebanyak $233 \%$ responden.

Perbedaan hasil citra positif Risma antara survey massa dan survey opinion leaders menunjukkan penilaian dan prioritas yang beda diantara kedua kelas sosial ini. Menurut survey massa penyediaan taman menjadi citra utama, namun bagi opinion leaders penyediaan taman bukan sebagai citra utama Risma. Citra Risma sukses mebuat taman pada peringkat ke empat. Seringnya Risma turun ke masyarakat meninjau permasalahan secara langsung membuat citra positif di kalangan opinion leader bukan taman, karena opinion leader berorintasi pada hasil kerja dan apa yang menjadi kebutuhan dari masyarakat Surabaya. Taman dinilai bukan menjadi kebutuhan utama, yang lebih harus diperhatikan oleh Risma yaitu masalah kemiskinan dan mengurangi pengangguran. Menurut opinion leaders pembangunan taman pun masih belum merata di seluruh wilayah Surabaya. 
Risma juga memiliki citra negatif yaitu Risma dinilai cenderung emosional dalam menyikapi sesuatu, apalagi kritikan. Seperti setiap ada proyek Pemkot yang tidak benar pembangunannya oleh kontraktor Risma langsung marah-marah. Kemarahan Risma juga terjadi ketika Taman Bungkul rusak akibat diinjak-injak karena ada acara pembagian Ice Cream Walls gratis, dan kemarahan itu diliput oleh media cetak dan elektronik baik lokal maupun nasional. "Sialan bener...bajingan semua.....lihat itu rusak semua," ujar Risma saat memarahi salah satu panitia bagi-bagi es krim Walls. Sebagai pemimpin menurut responden harus sebagai contoh masyarakatnya, namun ada juga responden yang justru suka dengan gaya kepemimpinan Risma seperti itu. Dengan gaya kepemimpinan Risma seperti itu diharapkan bisa memberikan perubahan di Kota Surabaya. Sebagian responden menilai bahwa harus bisa dibedakan ketegasan dengan kata-kata kotor. Seorang Ridwan Kamil memimpin kota Bandung dengan ketegasan tanpa menggunakan kata-kata kasar. Sifat Risma yang emosional ini banyak dikritisi oleh kelompok opinion leaders.

Sebanyak $40.80 \%$ responden massa menilai Risma emosional, sedangkan opinion leaders $39.80 \%$. Citra negatif selanjutnya yaitu komunikasi Risma buruk baik personal maupun antar lembaga pemerintahan. Responden survey massa sebanyak $14.70 \%$ menilai Risma komunikasinya buruk, sedangkan opinion leaders sebanyak $15.90 \%$ responden juga menilai Risma buruk dalam berkomunikasi. Buruknya komunikasi Risma bisa dilihat dari tegangnya hubungan Risma dengan DPRD Kota Surabaya selama menjabat. Setelah peristiwa adanya upaya pemakzulan oleh DPRD. Pencitraan memang menampilkan sisi rasionalitas dan sekaligus emosional. Pencitraan juga didukung dengan siapa yang bicara, ketika seorang Walikota mengambil kebijakan tentunya banyak media yang memberitakannya, apalagi jika kegiatan tersebut bersentuhan langsung dengan masyarakaat. Sekecil apa pun perbuatan itu akan memberikan persepsi positif dan akan memberikan citra positif pula pada kalayak ramai.

Mayoritas responden memang masih menilai kinerja Risma selama menjabat cukup bagus. Kepuasan masyarakat dengan kinerja Risma masih signifikan, dilihat dari survey yang dilakukan pada responden massa masih menilai Risma merupakan Walikota yang bagus, dengan gaya kepemimpinannya yang berani mengoreksi langsung pada pihak-pihak yang tidak sesuai dengan ketentuan. Namun responden opinion leader walaupun menilai kinerja Risma cukup bagus namun juga memberikan kritikan terhadap kebijakan Risma yang kadang lebih mengedepankan pendekatan populis bukan mendasarkan pada kebutuhan. Sebagai orang yang menjadi Walikota dari karir birokrasi dan kurang baiknya hubungan Risma dengan Parpol pengusungnya sendiri PDI Perjuangan, maka mau tidak mau Risma harus menggalang dukungan dari stake holder lainnya seperti media massa, dan pemilihnya langsung. Risma bahkan menjadi media darling karena tindakan-tindakannya diluar pakem pejabat namum berefek besar pada popularitas.

Kebijakan Risma untuk mebuat beberapa taman di Surabaya sampai banyak mendapatkan penghargaan walaupun rintisan taman-taman yang ada itu sudah dimulai oleh Walikota sebelumnya yaitu Bambang DH. Persepsi dipengaruhi oleh tiga faktor: karakteristik yang mempersepsikan, meliputi kebutuhan, pengalaman, norma-norma yang melingkupi (Anwar 2014). Dari segi kebutuhan terhadap program yang dilakukan Risma ada perpedaan persepsi antara massa dan opinion leaders. Opinion leaders melihat program yang lebih mendesak untuk masyarakat Surabaya bukan taman namun penciptaan lapangan kerja dan penanggulangan kemiskinan. Perbedaan persepsi ini memang dipengaruhi kebutuhan, pengalaman, dan norma-norma yang melingkupi responden massa maupun opinion leaders. Hal tersebut dipengaruhi juga oleh hasil dari pencitraan yang dilakukan Risma. Bahkan pembentukan citra dalam perkembangan sekarang dilakukan oleh tim profesional (image maker) yang betujuan untuk membentuk citra publik yang positif. Bahasa tubuh, intonasi suara, juga menjadi perhatian khususnya bagi pejabat politik. Untuk membentuk citra positif juga bisa dilakukan dengan memanipulasi khalayak ramai (Bruce B 1992).

Apa yang dilakukan Risma selama menjabat menyentuh perasaan masyarakat atau khalayak ramai. Banyaknya masyarakat yang suka terhadap apa yang dilakukan Risma, termasuk media massa baik cetak atau elektronik bergantian memberitakan Risma sehingga lama kelamaan Risma menjadi media darling. Nilai-nilai yang diterima oleh masyarakat atas apa yang dilakukan Risma lama-kelamaan 
bisa membentuk sikap politik masyarakat. Sikap masyarakat atas Risma yang sudah terbentuk membuat masyarakat khususnya pemilih atau pendukung Risma menjadi pemilih emosional, dimana setiap apa yang dilakukan Risma menjadi sebuah kebenaran mutlak. Pendukung Risma akan tetap menilai benar dan tetap memberikan rasa simpatiknya walaupun apa yang dilakukan Risma masih belum memberikan perbaikan dan penanganan permasalahan di Kota Surabaya secara signifikan. Sadar atau tidak sadar apa yang dilakukan Risma cenderung mengarah pada kapitalisasi citra positif Risma untuk penggalangan dukungan pada Pilkada Kota Surabaya Tahun 2015. Namun citra positif Risma itu menyembunyikan realitas yang ada. Realitas yang terbentuk merupakan bentukan dari pemberitaan yang dilakukan oleh media massa, dimana di dalam media massa terdapat agenda-setting (Maxwell McComb 2013). Ada realitas lain yang cenderung disembunyikan Risma selama menjabat Walikota. Seperti rendahnya penyerapan anggaran, yang hanya sekitar 80 persen, dari APBD Tahun 2014 Rp. 7,26 triliun pada akhir tahun dikembalikan Rp.1,2 triliun. Dari pengelolaan anggaran seharusnya bisa dimaksimalkan lagi untuk kesejahteraan masyarakat dan infrastruktur. Risma juga tegas hanya pada pihak-pihak yang lemah, namun ketika dihadapkan dengan permasalahan besar seperti pemodal besar Risma juga tidak bersikap. Seperti kasus Waduk Sepat yang melibatkan Ciputra, sebagai Walikota Risma seharusnya bersikap walaupun keputusan tukar guling Waduk Sepat pada pemerintahan Bambang DH. Namun apakah berani Risma meninjau kembali SK Walikota Surabaya Nomor 188.145.366/436.1.2/2008 Tentang Pemindahtanganan Dengan Cara Tukar Menukar Terhadap Aset Pemerintah Kota Surabaya Berupa Eks Ganjaran/Bondo Desa di Kelurahan Beringin, Kecamatan Lakarsantri, dan Kelurahan Jeruk, Kecamatan Lakarsantri, serta Kelurahan Babat Jerawat, Kecamatan Pakal, Kota Surabaya, dengan Tanah Milik PT. Ciputra Surya. Sebagai kota yang langganan banjir tiap tahunnya Waduk Sepat sangat berperan untuk menampung air hujan atau sebagai resapan.

Hal yang sama juga terjadi pada terancamnya kawasan mangrove di Wonorejo, Rungkut atas aktifitas perumahan baru yang berbatasan langsung dengan wilayah konservasi. Risma pernah mengeluarkan pernyataan akan mengembalikan luas wilayah konservasi yang dari tahun ke tahun semakin berkurang dengan pembebasan lahan namun juga belum terealisasi. Ada developer yang belum mempunyai AMDAL namun sudah melakukan aktifitas pengurukan, dan sudah melakukan pembangunan perumahan walaupun IMB masih tunggal. Ternyata Walikota tidak melakukan tindakan apapun, sampai ada developer yang sudah melakukan pembangunan perumahan sampai tahap ke-3. Sebagai walikota yang peduli denga lingkungan juga seharusnya melindungi dan peduli dengan pelestarian mangrove di sisi timur Surabaya.

Realitas yang ada masyarakat Surabaya masih membutuhkan penanganan problem mendasar seperti penciptaan lapangan kerja baru dan upaya penanganan kemiskinan di perkotaan. Sesuai data BPS Jatim jumlah pengangguran di Kota Surabaya cenderung naik sejak Tahun 2012-2014. Sesuai data BPS Kota Surabaya 2015 jumlah pengangguran Tahun 2012 berjumlah 71,99 ribu jiwa, Tahun 2013 jumlahnya meningkat menjadi 77,86 ribu jiwa dan Tahun 2014 meningkat lagi mencapai 85,34 ribu jiwa. Begitupula di Kota Surabaya masih cukup banyak masyarakat miskin terutama di pinggiran Surabaya. Kemiskinan yang kurang tersentuh program menyebabkan disparitas antara warga perkotaan dan warga pinggiran Surabaya. Banjir dan kemacetan juga menjadi permasalahan Kota Surabaya yang perlu segera ditangani oleh Risma sebagai Walikota Surabaya. Namun selama menjabat Risma cenderung reaktif, melakukan kegiatan yang hanya memunculkan simpati dan popularitas. Risma lebih terbuai dengan program pembangunan taman-taman kota yang mengantarkan Risma mendapatkan penghargaan dari PBB. Sikap Risma yang reaktif dan spontanitas menarik simpati masyarakat, termasuk Risma ketika marah-marah, terjun langsung mengatur kemacetan, meninjau banjir dipersespsikan masyarakat sebagai bentuk kehadiran sebuah negara. Apa yang dilakukan oleh Risma itu merupakan tindakan untuk pembentukan berita yang bertujuan untuk citra positif. Menurut Zaller (1999:1),

"The weapons of combat are press conferences, photo opportunities, news releases, leaks to the press, and "spin." When the stakes are especially high, TV and radio advertisements may be used. Politicians still make backroom deals, but only after their relative strength has been established in the public game of "media politics". 
Pemilih kadang juga kurang mendapatkan inforamasi yang komplet tentang isu-isu politik. Bahkan informasi politik cenderung langka. Ironisnya banyak masyarakat dalam menerima informasi tidak mencari berita pembanding untuk mencari kebenaran berita. Sehingga apa yang diberitakan oleh media menjadi satu-satunya sumber informasi dan menjadi kebenaran mutlak. Seperti yang dikemukakan oleh Lupia \& McCubbins (1998:6),

\begin{abstract}
"Ironically, for many political issues, information is not scarce, rather it is the cognitive resources that a person can use to process information that are scarce. For example, political information appears in the newspapers, in the mail, on community bulletin boards, and on television and radio and is relayed to us in person by friend and family. People often lack the time and energy needed to make sense of all this informations. As a consequence, people often have incomplete information".
\end{abstract}

Persepsi masyarakat terhadap walikota, adalah walikota yang setiap saat hadir, merakyat dan mampu mengatasi permasalahan yang ada, namun apa yang dilakukan Risma ternyata masih kalah cepat dengan problematika yang ada di Kota Surabaya. Sebuah kebijakan tidak hanya bisa mengatasi permasalahan kota namun juga harus bisa memprediksi permasalahan Kota Surabaya. Risma hanya bermain pada kebijakan politik level bawah (low level political issues), belum melakukan kebijakan politik tingkat atas (high level political issues) dimana kebijakan yang menjawab permasalahan sesuai realitas yang ada termasuk seorang Walikota Surabaya harus berani bersikap terhadap konflik tanah dan lingkungan yang menggejala di Kota Surabaya, tidak jarang melibatkan pengusaha kontraktor. Beberapa kasus konflik tanah dan lingkungan Risma tidak bersikap selayaknya keperpihakannya terhadap pembangunan taman-taman kota.

\title{
Simpulan
}

Selama menjabat Walikota Surabaya periode 2010-2015 kebijakan yang dilakukan Risma hanya melakukan kebijakan yang populis, kebijakan yang hanya menggugah perasaan (emosi) masyarakat saja dan cenderung menyembunyikan realitas yang ada. Sebagai bentuk kehadiran negara, apa yang dilakukan Risma sudah bisa dikatakan bagus dengan sering sidak, terjun langsung mengatasi kemacetan jalan, peninjauan banjir, namun apa yang dilakukan Risma tidak harus dilakukan terus menerus bisa didelegasikan kepada Wakil Walikota atau Kepala Dinas. Pendelegasian sebagian kewenangan Risma juga untuk menunjukkan bagaimana kepemimpinan itu collective collegial bukan kepemimpinan yang mencerminkan one men show. Tindakan Risma sebagai Walikota Surabaya lama kelamaan menumbuhkan rasa simpati masyarakat atau khalayak ramai. Reproduksi citra positif tindakan yang dilakukan oleh Risma ketika diliput oleh media massa baik cetak maupun elektronik akan membentuk sikap dan perilaku masyarakat.

Apa yang dilakukan Risma lebih pada pencitraan politik. Pencitraan politik bisa dilakukan oleh pejabat politik dalam hal ini Tri Rismaharini disadari atau pun tidak, atau dilakukan oleh individu atau dengan bantuan tim/konsultan. Apalagi Risma sudah menjadi media darling sehingga setiap apa yang dilakukan dan diucapkan menjadi perhatian khalayak ramai dan cenderung menjadi entitas kebenaran itu sendiri. Sebagai politisi melakukan pencitraan memang sesuatu hal yang wajar dan boleh dilakukan asalkan pencitraan yang dilakukan sesuai dengan realitas yang ada, atau justru pencitraan yang dilakukan tidak ada hubungannya dengan realitas yang ada. Hal ini seperti yang dikemukakan oleh Baudrillard (2006) it bear no relation to any reality whatever: it is its own pure simulacrum. Terjadi kekaburan antara simulakra dengan realitas yang ada sehingga masyarakat mempersepsikan Tri Rismaharini sebagai Walikota yang peduli dengan lingkungan, membela wong cilik, dan sering terjun ke masyarakat.

Hal ini bisa terjadi karena media massa, termasuk media sosial menyampaiakan pesan politik hasil dari rekonstruksi dari realitas yang sesungguhnya. Realitas yang disampaikan oleh media kadang merupakan realitas yang sudah dikemas atau realitas tangan kedua (second hand reality), karena realitas itu dibuat oleh wartawan, dan redaktur yang mengolah peristiwa politik menjadi berita politik, 
melalui proses penyaringan dan seleksi. Walaupun adakalanya media menampilkan realitas buatan yang tidak sesuai dengan realitas yang sebenarnya, namun tetap banyak kalangan dalam masyarakat cenderung menerima begitu saja informasi dari media massa, tanpa melakukan pengecekan terlebih dahulu. Itulah sebabnya banyak orang yang terkecoh dengan berita yang ditampilkan oleh media massa. Apa yang dilakukan Risma hanya pada ranah low level political issues.

Pemilih kritis lebih menginginkan kebijakan yang mendasar dan substantif. Risma sebagai Walikota Surabaya dengan segala kewenangan dan kekuasaannya diharapkan juga mengeluarkan kebijakankebijakan yang mendasar dan berani bersikap tidak hanya pada pihak-pihak yang mempunyai sumbersumber terbatas (lemah) namun juga mampu mengatasi permasalahan sesuai dengan realitas yang ada. Risma juga harus mampu bersikap terhadap pihak-pihak yang mempunyai sumber-sumber tak terbatas (kuat) seperti pengusaha terutama terkait dengan konfik tanah dan lingkungan di Surabaya. Sebagai Walikota Surabaya Risma juga harus bisa bermain pada high level political issues.

\section{Daftar Pustaka}

Anwar A (2014) Politik Pencitraan-Pencitraan Politik. Yogyakarta: Graha Ilmu.

Baudrillard J (2006) Simulacra and Simulation. USA: Michigan University Press.

Bruce B (1992) Images of power: How the image makers shape our leaders. London: Kogan Page

Davis R \& Owen D (1998) New Media and American Politics. New York: Oxford University Press.

Hacker K L (1996) Missing links in the evolution of electronic democratization. Media, Culture \& Society 18(2):213-232.

Kendall KE \& Paine SC (1995) Political Image and Voting Decisions. In: KL Hacker (ed). Candidate Image In Presidential Election. Westport CT: Praeger.

Kendall KE \& Yum JO (1984) Persuading the blue-collar voter: Issues, images, and homophily. Annals of the International Communication Association 8(1):707-723.

Lippmann W (1946) Public Opinion. New Jersey: Transaction Publishers.

Lupia A \& McCubbins M D (1998) The Democratic Dilemma: Can Citizens Learn What They Need to Know? Cambridge: Cambridge University Press.

McCombs M (2013) Setting the Agenda: The Mass Media and Public Opinion. John Wiley \& Sons.

Neuman W R (1986) The paradox of mass politics. Cambridge: Harvard University Press.

Nimmo D (1976) Political image makers and the mass. The ANNALS of the American Academy of Political ans Social Science 427:33-44.

Nimmo D, Savage RL (1976) Candidates And Their Images: Concepts, Methods, And Findings. Pacific Palisades, CA: Goodyear Publishing Company.

Rosenberg WS, Kahn S, Tran T (1991) Creating a political image: shaping appearance and manipulating the vote. Political Behavior 13(4):345-367.

Trout J \& Ries A (1982) Positioning: The battle for your mind. Replay Radio, Radio New Zealand.

Zaller John (1999) A Theory of Media Politics: How the Interests of Politicians, Journalist, and Citizens Shape the News. Chicago: University of Chicago Press.

http://m.beritajatim.com/ekonomi/234261/pedagang_di_sentra_pkl_surabaya_terancam_bangkrut.htm 1. 